\title{
Associations between stormwater retention pond parameters and pollutant (suspended solids and metals) removal efficiencies
}

\author{
IC Brink ${ }^{1 *}$ and W Kamish ${ }^{2}$ \\ 'Department of Civil Engineering, University of Stellenbosch, Private Bag X1, Matieland 7602, South Africa \\ ${ }^{2}$ Tonkin and Taylor, PO Box 5271, Wellesley Street, Auckland, 1141, New Zealand
}

\begin{abstract}
Presented in this paper are the results of correlational analyses and logistic regression between metal substances $(\mathrm{Cd}, \mathrm{Cu}$, $\mathrm{Pb}, \mathrm{Zn}$ ), as well as suspended solids removal, and physical pond parameters of 19 stormwater retention pond case studies obtained from the International Stormwater BMP database. Included are cross-correlations between metals and solids in pond influent, effluent and removals. The findings provide insights fundamental to further development of improved models and design guidelines for stormwater ponds. Indications were that (i) pond efficiencies differed between high and low influent concentrations and masses, (ii) concentration was an invalid indicator of correlations between substances in pond influent and effluent as well as the fractions of substances removed within ponds, (iii) total cadmium, copper, lead, zinc and total suspended solids (TSS) were associated in surface runoff and similarly removed within ponds, (iv) statistically significant correlations were often only found in data groups either above or below a specific statistic (quartile value, median) for specific pond parameters, indicating that removals may have been differently influenced by pond parameters over different data ranges, and (v) the volume within the permanent pool was of greater importance to pond efficiencies than the volume captured during storm events.
\end{abstract}

Keywords: stormwater, pond efficiency, detention pond, retention pond, effluent probability method, mass, concentration

\section{INTRODUCTION}

Pollution can impair surface water quality. The United Nations asserts that clean water and healthy freshwater ecosystems are the basis upon which many livelihoods depend, including irrigation water, fertile farmlands, and environments for aquaculture. Good quality water has been less emphasised in the past than the need for adequate quantities of water. However, both are essential, and polluted water can decrease or eliminate the viability of many livelihoods (UNEP, 2010).

The most common contaminants, other than sediment, reported in surface and shallow ground waters are metals (see Kang et al., 2009; Kang et al., 2010; Naito et al., 2010; Plauborg et al., 2010; Zgheib et al., 2012). The USA nationwide urban runoff programme found as early as 1983 that heavy metals (including copper, zinc and lead) were the most prevalent priority pollutants in urban runoff within the country; with some metals present often enough, and in signficant enough concentrations, to potentially threaten beneficial uses (USEPA, 1983).

Metal toxins are typically found to be at trace concentrations and may not be seen as an acute threat. Such notions, however, overlook insidious metal behaviour in the environment, e.g., (i) metals such as arsenic, cadmium, copper, lead and zinc are strongly sorbed to soil clay particles and can be expected to be retained in soil surface layers over long periods of time, with accumulation to phytotoxic levels before equilibrium between sorption and desorption is reached, and (ii) certain metal toxins such as arsenic, cadmium and lead are known to bioaccumulate in crops and animals (DWAF, 1996).

To whom all correspondence should be addressed.

용 +27218084195 ;

e-mail: icbrink@sun.ac.za

Received 23 January 2017, accepted in revised form 4 December 2017.
Arsenic, cadmium, copper, lead and zinc are strongly adsorbed by soil clay particles and can be expected to be retained in the soil surface layers (DWAF, 1996). This build up of toxins may, over time, threaten the health of living organisms, including humans, that utilise polluted land and concomitant freshwater systems as food and water sources.

In many parts of the world, point sources of pollution are now well controlled and pollution of aquatic systems is thought to be mostly due to non-point source distribution of contaminants across the landscape and from the atmosphere (UNEP, 2006). Detention and retention ponds have been used internationally to intercept polluted stormwater runoff. However, prominent international design philosophies and methodologies from countries such as the USA, the UK and Australia do not directly address the removal of metal pollutants. Brink (2016) reviewed published design methodologies emanating from these countries and found that they do not include the array of parameters found to be influential in the functioning of the studied ponds or consider all of the important processes, such as re-suspension. These methodologies were therefore concluded to be inadequate for application towards metal removals in ponds.

Research towards the determination of pond performance based on design factors includes the works of Hossain et al. (2005), Lampe et al. (2005), Barrett (2008) and Dufresne et al. (2010). Limitations of these studies included the amount of metal pollutants they investigated, the number of pond physical characteristics included, and/or a focus only on pollutant concentrations (not masses).

This research comprises a retrospective cross-case investigation performed on multiple retention pond case studies stemming mainly from the USA. The objective of the study was to obtain insight into physical pond characteristics that influence pond efficiencies in terms of the removal 
of metals known to have possible adverse effects on the environment. A limited number of metals and metalloids were chosen for inclusion, according to harm potential and prevalence. These were $\mathrm{Cd}, \mathrm{Cu}, \mathrm{Pb}$ and $\mathrm{Zn}$.

Correlation analyses and logistic regression were performed between metal substance $(\mathrm{Cd}, \mathrm{Cu}, \mathrm{Pb}, \mathrm{Zn})$ as well as solids (total suspended (TSS) and total volatile (TVS)) removal and pond physical characteristics of 19 retention pond case studies. Additionally, an investigation of cross-correlations between metals and solid substances in pond influent, effluent and removal was included. Although the 19 case studies included large amounts of data overall, small individual data sets and associated limitations negated detailed investigations. Therefore, the methodology was focused on elucidating data trends rather than specifics.

\section{METHODS}

Data was obtained from the International Stormwater BMP database (2012). It consisted of event mean concentrations (EMCs) and total flow volumes per storm event for each case study. Approximate metals, total suspended solids (TSS) and total volatile solids (TVS) masses per storm event were derived from this information.

In the past, the use of the concentration parameter has been favoured in general stormwater structure efficiency determinations (see Greb and Bannerman (1997), Strecker et al. (2001), Hossain et al. (2005), Barrett (2008)). This prompted its inclusion in this analysis even though the main focus was on the mass parameter. The term 'concentration removal' has been used in this section. Concentration is a compound variable and can, strictly speaking, not be removed. This term must therefore be understood to refer to the mathematical definition of the variable $C_{r e m}$ as defined in Eq.1 below, and not to its linguistic definition.

Correlational analysis and logistic regression required pond efficiencies to be characterised in a numerical form. Correlation of pond efficiencies per case study with different pond physical parameters (length, width etc.) meant that a single numerical descriptor of efficiency was required per case study. Fraction removal values were calculated to this end and used in all analyses as follows:

Concentration and mass influent data for all case studies were combined, ordered per storm event and ranked with associated fraction removal values:

$$
\begin{aligned}
& C_{r e m}=\left(C_{\text {in }}-C_{\text {out }}\right) / C_{\text {in }} \\
& M_{\text {rem }}=\left(M_{\text {in }}-M_{\text {out }}\right) / M_{\text {in }}
\end{aligned}
$$

Where $C_{\text {in }}$ is the influent EMC per storm event, $C_{\text {out }}$ is the effluent EMC value associated with $C_{i n}$ per storm event, $C_{\text {rem }}$ is the fraction of concentration 'removed' per storm event, $M_{i n}$ is the influent mass value per storm event, $M_{\text {out }}$ is the effluent mass value associated with $M_{i n}$ per storm event and $M_{\text {rem }}$ is the fraction of mass removed per storm event. These calculations were performed per storm event.

\section{Pond efficiencies over different data ranges}

Literature pertaining to stormwater retention pond removals has alluded to different removals at different concentrations, i.e., discharge concentrations may be a function of influent concentrations (see Lampe, 2005). This prompted an initial investigation into pond removals over different data ranges. The purpose was the determination of influent data sub-sections that have similar removal efficiencies. Data from identified subsections were grouped and averaged to provide a single numerical descriptor of efficiency required for further correlational analyses between substance removals and pond parameters.

Ranked influent data sets (with associated $C_{\text {rem }}$ or $M_{\text {rem }}$ values) were split into two sub-sections at the following influent data values: first quartile (Q1), third quartile (Q3) and median. Small sample sizes per case study meant that data could be grouped into a maximum of two sub-sections to enable as much data overlap as possible between case studies in subsequent correlational analyses. The Mann-Whitney $U$-test was used to determine significant differences in $C_{\text {rem }}$ or $M_{\text {rem }}$ between the different groups at $p \leq 0.05$. Where significant differences were found, groups were averaged. These average values were used as input into correlational analysis between substance removals and pond parameters.

\section{Cross-correlations between substances}

Correlations between different metals and suspended solids were investigated in pond influent, effluent and fraction removals within ponds. This was done to ascertain whether different substances were associated with each other in these areas. Metal and suspended solids data from all case studies were combined per associated storm event and case study and correlated. The non-parametric Spearman correlation coefficient $(R)$ was used. Strong correlations $(R \geq 0.8)$ that were statistically significant at $p \leq 0.05$ were reported.

\section{Relationships between substance removals and pond parameters}

Correlation analysis was used to determine the strength of association between substance mass fraction removals $\left(M_{\text {rem }}\right)$ and physical pond parameters (volume, depth, etc.) for the different case studies. Logistic regression was used to find predictor variables in terms of physical pond parameters for statistically significant efficiencies and negative removals.

Concentration and mass fraction removals $\left(C_{r e m}\right.$ and $\left.M_{r e m}\right)$ were calculated for all storm events from all case studies. Influent concentrations and masses for the combined data sets of all case studies were ranked with their associated fraction removal values per substance (metal or TSS). Influent values with associated effluent and fraction removal values were then split into two groups according to the chosen Q1, Q3 or median split. The average fraction removal was calculated for each split group as well as for the total data sets (all data with no data split).

Information on physical pond parameters was compiled from the International Stormwater BMP Database and literature referenced in the database. These included permanent pool volume $(\mathrm{Vpp})$, flood control volume $(\mathrm{Vfc})$, surcharge detention volume (Vsd), watershed area (WA), littoral zone surface area (SAlz), permanent pool surface area (SApp), surcharge detention surface area (SAsd), permanent pool length (Lpp), permanent pool depth (dpp), surcharge brimfull emptying time (SBF) and the estimated percentage of the watershed that was impervious (\%Imperv.) (See Wright Water Engineers \& Geosyntech, Inc. (2010) for a full explanation of these terms). Combinations of these parameters were also used, e.g., $\mathrm{Vpp} / \mathrm{Vfc}, \mathrm{Vpp} / \mathrm{Vsd}$ etc.

Data were ordered into 3 sections to investigate pond functioning in cases, viz. (i) 'all data', i.e., all data including 
positive and negative data, (ii) 'positive data only', i.e., data where influent values were greater than effluent values per storm event and (iii) 'negative data only', i.e., data where influent values were less than effluent values per storm event. Significant Spearman correlation coefficients and $R$ (at $p \leq$ 0.05 ) between fractional removal values and physical pond parameters were reported.

\section{Logistic regression}

Possible relationships between pond physical parameters and efficiencies were investigated as follows: Pond efficiencies for masses were classified according to the Effluent Probability Method as described in Brink and Kamish (2016a). They were then coded for 'significantly positive efficiency' (code $=1$ ) vs. 'not significantly positive efficiency' (code $=0$ ). The data were used as input to the software program Statistica v.10 (StatSoft, Inc. 1984-2011). Logistic regression modelling was employed to determine parameters of the best predictor models ( $p \leq 0.05)$.

Possible relationships between pond physical parameters and negative average fraction mass removal were investigated. Average fraction removals for all substances were grouped according to the case study and coded for 'negative' (code $=1$ ) vs. 'positive' (code $=0$ ) average substance mass removals. The data were used as input to the software program Statistica v.10 (StatSoft, Inc. 1984-2011). Logistic regression modelling was employed to determine parameters of the best predictor models.

\section{RESULTS AND DISCUSSION}

\section{Retention pond parameters and design characteristics}

The case studies that yielded useable data are summarised with their respective design information in Table 1.

\section{Pond efficiencies over different data ranges}

The results of the investigation into pond efficiencies over substance data ranges are displayed in Table 2 for mass removals only. Concentration analyses were suspended for the investigation into relationships between substance removals and pond parameters (see further discussion below).

As alluded to in the literature (see Lampe, 2005), there were statistically significant differences between upper and lower concentration and mass removal groups. This confirms that ponds removed metals and suspended solids differently depending on whether the influent loads are high or low. This finding therefore negates a 'one solution to all problems' design idea. Instead, retention pond design should take into consideration the expected load magnitude from a catchment area. Future pond design, therefore, has to be informed by this typical pond behaviour to ensure correct design response to the expected runoff load from a catchment.

The results in Table 2 were used to group data for input into the correlational analysis between substance removals and pond parameters. The statistics (Q1, median or Q3) at which significant differences between groups were found are summarised in Table 3. The statistics used in subsequent correlational analyses are displayed in bold.

\section{Cross-correlations between substances}

It can be seen from Tables 2 and 3 that the most common statistic by which data could be split to find statistically significant differences between low and high fraction removals was the median. This general dominance of the median motivated the choice of this statistic as the default in all cases in which it appeared. No single statistic was found to appear in all data sets and an investigation into the required statistic for a specific data set is recommended in situations where the methodology used in this project is applied.

In Table 4 it can be seen that significantly correlated concentration groups often differed from mass correlations. This indicated that the influence of influent volume affected correlation results for the compound parameter concentration in such a way that correlations between substances were confounded. It was accepted that mass data correlations provided the most valid information on relationships between substances (also see Brink and Kamish, 2016b).

All total masses showed strong $(R \geq 0.8)$ and significant ( $p$ $\leq 0.05$ ) correlations with each other, with TSS, and with TVS in the pond influents and effluents. These substances were therefore associated in surface runoffs and pond effluents, indicating similar removal mechanisms within ponds.

All dissolved metal masses correlated with TSS in the influent mass section, indicating some relationship between particulate and dissolved matter in runoff streams. This may have been due to an external relationship between substances and flow volumes, i.e., when flow volumes increased then the masses of materials they carried increased proportionally, regardless of whether they were in particulate or dissolved form. No correlations were found in the effluent or fractionremoved sections.

All particulate metal masses correlated with TSS in the influent mass section. Zinc correlated with TVS as well, indicating zinc content in the organic particulate material. Particulate copper, lead, zinc and TSS correlated in the effluent section as well, indicating similar removals of these materials within the pond. Particulate zinc, copper and lead also correlated in the fraction-removed section, lending support to this indication. These findings are similar to those of Borris et al. (2016) and Djukić et al. (2016).

\section{Relationships between substance removals and pond parameters}

Analysis results are displayed in Tables 5, 6 and 7 below. Table 5 below shows the significantly positive Spearman correlation coefficients $(R)$ for pond parameters and mass fraction removals, for positive removals only, negative removals only, and all data (including positive and negative removals). In no case did concentration removal correlations have corresponding mass removal correlations. This illustrates that concentration and mass parameters were not interchangeable. Only mass results were therefore reported and further discussed. No correlations with dissolved or particulate data were found. This may have been due to insufficient data for these fractions since correlations were found for total substances, which were composed of dissolved and particulate material. Many case studies had highly limited or no dissolved data. Out of the 19 ponds, only 2 had dissolved cadmium data, 4 had dissolved copper data, 6 had dissolved lead data and 4 had dissolved zinc data.

The results contained few correlations with basic pond parameters such as Vpp, SApp (a similar result for TSS concentrations was found by Lampe (2005)), Lpp and Wpp in relation to combinations of parameters such as Vpp/Vfc, Vpp/ Vsd, etc. This indicates that the ponds functioned as a system 


\begin{tabular}{|c|c|c|c|c|}
\hline \multicolumn{5}{|c|}{$\begin{array}{c}\text { TABLE } 1 \\
\text { Case study retention pond parameters } \\
\text { (Information compiled from listed references and the International Stormwater BMP Database, 2012) }\end{array}$} \\
\hline Case study & Approximate shape & Design basis & Reference & $\begin{array}{l}\text { Pond location (place and } \\
\text { coordinates (lat., long.)) }\end{array}$ \\
\hline Central Park & $\begin{array}{l}3 \text { areas: triangle, squat } \\
\text { rectangle and long } \\
\text { rectangle }\end{array}$ & Unknown & $\begin{array}{l}\text { International } \\
\text { Stormwater BMP } \\
\text { database }(2012)\end{array}$ & $\begin{array}{l}\text { Austin, USA } \\
(30.303333,-97.739333)\end{array}$ \\
\hline Cockroach Bay & $\begin{array}{l}2 \text { areas: triangle and squat } \\
\text { rectangle }\end{array}$ & Unknown & Rushton (2002) & $\begin{array}{l}\text { Ruskin, USA } \\
(27.683333,-82.500000)\end{array}$ \\
\hline De Bary & Squat rectangle & $\begin{array}{l}\text { Florida Administrative } \\
\text { Code Chp. } 40 \mathrm{C}-42 \text { : capture } \\
\text { specified volume and have } \\
\text { specified draw down time }\end{array}$ & Harper and Herr (1993) & $\begin{array}{l}\text { DeBary, USA } \\
(28.876300,-81.297700)\end{array}$ \\
\hline Greens Bayou & Squat rectangle & Surge Basin & $\begin{array}{l}\text { Wetland Solutions Inc. } \\
(2010)\end{array}$ & $\begin{array}{l}\text { Houston, USA } \\
(29.931000,-95.208000)\end{array}$ \\
\hline Heritage Estates & L-shape & $\begin{array}{l}\text { Pre-development flow rates } \\
\text { for } 5 \text { and } 100 \mathrm{yr} \text { storms }\end{array}$ & $\begin{array}{l}\text { SWAMP Program } \\
(2005)\end{array}$ & $\begin{array}{l}\text { Richmond Hill, Canada } \\
(43.881667,-79.464167)\end{array}$ \\
\hline I5 La Costa East & Triangle & $\begin{array}{l}\text { Water quality volume } \\
\text { approach }\end{array}$ & $\begin{array}{l}\text { California Department } \\
\text { of Transportation (2004) }\end{array}$ & $\begin{array}{l}\text { Encinitas, USA } \\
(33.084722 \\
-117.300000)\end{array}$ \\
\hline Lake Ellyn & Rectangle & $\mathrm{n} / \mathrm{a}$ & $\begin{array}{l}\text { Striegl and Cowan } \\
\text { (1987) }\end{array}$ & $\begin{array}{l}\text { Glen Ellyn, USA } \\
(41.880400,-88.062300)\end{array}$ \\
\hline Lakeside & Long triangle & Runoff quantity control & Wu (1989) & $\begin{array}{l}\text { Charlotte, USA } \\
(35.226400,-80.799000)\end{array}$ \\
\hline Lake Ridge & Long triangle & $\begin{array}{l}\text { According to EPA } \\
\text { guidelines }\end{array}$ & Walker (1993) & $\begin{array}{l}\text { Woodbury, USA } \\
(44.913100,-92.33800)\end{array}$ \\
\hline $\begin{array}{l}\text { Madison Monroe } \\
\text { str. }\end{array}$ & Triangle (curved sides) & $\begin{array}{l}\text { Water quality (design } \\
\text { method unknown) }\end{array}$ & House et al. (1993) & $\begin{array}{l}\text { Madison, USA } \\
(43.152500,-89.435556)\end{array}$ \\
\hline McKnight Basin & $\begin{array}{l}2 \text { areas: triangle and } \\
\text { indeterminable shape }\end{array}$ & Unknown & Oberts et al. (1989) & $\begin{array}{l}\text { Maplewood, USA } \\
(45.015500,-93.043500)\end{array}$ \\
\hline $\begin{array}{l}\text { Phantom Lake } \\
\text { Pond A }\end{array}$ & $\begin{array}{l}3 \text { areas: triangle, squat } \\
\text { rectangle, rectangle }\end{array}$ & $\begin{array}{l}\text { King County Water } \\
\text { Quality Design Manual } \\
\text { (King County 1990): } \\
\text { assumed } 80 \% \text { TSS removal } \\
\text { with design volume at least } \\
3 \text { times mean annual storm } \\
\text { runoff volume }\end{array}$ & Comings et al. (2000) & $\begin{array}{l}\text { Bellevue, USA } \\
(47.583333 \\
-122.100000)\end{array}$ \\
\hline Pinellas & L-shape & $\begin{array}{l}\text { Runoff quantity control } \\
\text { and water quality } \\
\text { improvement (design } \\
\text { method unknown) }\end{array}$ & $\begin{array}{l}\text { Kantrowitz and } \\
\text { Woodham (1995) }\end{array}$ & $\begin{array}{l}\text { Pinellas Park, USA } \\
(27.846100,-82.702900)\end{array}$ \\
\hline Pittsfield & Irregular rounded & Unknown & $\begin{array}{l}\text { International } \\
\text { Stormwater BMP } \\
\text { database (2012) }\end{array}$ & $\begin{array}{l}\text { Ann Arbor, USA } \\
(42.247600,-83.826100)\end{array}$ \\
\hline Runaway Bay & Long triangle & Runoff quantity control & Wu (1989) & $\begin{array}{l}\text { Charlotte, USA } \\
(35.226400,-80.799000)\end{array}$ \\
\hline Silver Star Rd & Rectangle & Unknown & $\begin{array}{l}\text { Martin and Smoot } \\
\text { (1986) }\end{array}$ & $\begin{array}{l}\text { Orlando, USA } \\
(28.544700,-81.378400)\end{array}$ \\
\hline $\begin{array}{l}\text { Tampa Office } \\
\text { Pond } 1\end{array}$ & Irregular L-shape & $\begin{array}{l}\text { Treatment volume }-0.5 \\
\text { inch watershed runoff }\end{array}$ & Rushton et al. (1997) & $\begin{array}{l}\text { Tampa, USA } \\
(28.149500,-82.442800)\end{array}$ \\
\hline $\begin{array}{l}\text { Tampa Office } \\
\text { Pond } 2\end{array}$ & Irregular L-shape & $\begin{array}{l}\text { As above, but with greater } \\
\text { pool fluctuation allowed }\end{array}$ & Rushton et al. (1997) & $\begin{array}{l}\text { Tampa, USA } \\
(28.149500,-82.442800)\end{array}$ \\
\hline $\begin{array}{l}\text { Tampa Office } \\
\text { Pond } 3\end{array}$ & Irregular rectangle & $\begin{array}{l}\text { Permanent pool with } 1 \text { inch } \\
\text { watershed runoff volume } \\
\text { and } 14 \mathrm{~d} \text { residence time }\end{array}$ & Rushton et al. (1997) & $\begin{array}{l}\text { Tampa, USA } \\
(28.149500,-82.442800)\end{array}$ \\
\hline
\end{tabular}


TABLE 2

Sub-range $p$-values (Mann-Whitney $U$-test) for 2 independent groups.

Values statistically significant at $p \leq 0.05$ are displayed in bold.

\begin{tabular}{|l|c|c|c|c|c|c|c|c|c|}
\hline Fraction & \multicolumn{3}{|c|}{ Total } & \multicolumn{3}{|c|}{ Dissolved } & \multicolumn{3}{c|}{ Particulate } \\
\hline Statistic & Q1 & Q3 & Median & Q1 & Q3 & Median & Q1 & Q3 & Median \\
\hline Cadmium & 0.616 & 0.575 & 0.098 & ID & ID & ID & ID & ID & ID \\
\hline Copper & $\mathbf{0 . 0 2 6}$ & $\mathbf{0}$ & $\mathbf{0 . 0 2 9}$ & $\mathbf{0 . 0 1 2}$ & 0.89 & 0.083 & 0.082 & 0.443 & $\mathbf{0 . 0 0 5}$ \\
\hline Lead & 0.149 & 0.131 & $\mathbf{0 . 0 3 6}$ & 0.556 & $\mathbf{0 . 0 0 9}$ & 0.248 & $\mathbf{0 . 0 1 2}$ & 0.185 & $\mathbf{0 . 0 0 5}$ \\
\hline Zinc & 0.648 & 0.082 & $\mathbf{0 . 0 1 4}$ & $\mathbf{0 . 0 0 1}$ & $\mathbf{0 . 0 4}$ & 0.695 & $\mathbf{0 . 0 1 9}$ & 0.825 & 0.756 \\
\hline TSS & 0.146 & $\mathbf{0 . 0 1 8}$ & 0.092 & NA & NA & NA & NA & NA & NA \\
\hline TVS & 0.586 & 0.913 & 0.477 & NA & NA & NA & NA & NA & NA \\
\hline
\end{tabular}

$I D=$ insufficient data, $N A=$ not applicable

TABLE 3

Chosen statistic within data sets for correlational analysis comparison between high and low influent loads.

The statistics used in subsequent correlational analyses are displayed in bold.

\begin{tabular}{|l|c|c|c|}
\hline Fraction & Total & Dissolved & Particulate \\
\hline Cadmium & None & ID & ID \\
\hline Copper & Q1, Q3, median & Q1 & Median \\
\hline Lead & Median & Q3 & Q1, median \\
\hline Zinc & Median & Q1, Q3 & Q1 \\
\hline TSS & Q3 & NA & NA \\
\hline TVS & None & NA & NA \\
\hline
\end{tabular}

ID = insufficient data,$N A=$ not applicable

without significant direct influences from the basic parameters. The absence of correlations with Vpp in the 'all data' section was in accordance with the findings of Barrett (2008) and Lampe (2005) for metals and TSS concentrations.

Patterns in the types of substances removed per parameter were not often observed. Copper had the highest number of correlations. The cross-correlational analysis between substances indicated that TSS, copper, lead, zinc and TVS masses were associated in pond removals. Paucity in correlation results for some of these mass substances was therefore taken to indicate a lack of data rather than a lack of relationships.

Correlations with data in different split groups, i.e., above or below the median, Q1 or Q3 indicate that removals may have been differently influenced by pond parameters over different data ranges. This once more indicates that design of retention ponds should include consideration of the runoff loads. Total copper removals, for example, are well correlated $(R=0.9)$ for ponds with higher littoral zone surface areas $\left(\mathrm{SA}_{1 z}\right)$ only for influent values below the data median. This indicates that littoral zones are efficient in removing copper only when the influent load is relatively lower than is commonly found in runoff.

Increased permanent pool volume in relation to the surcharge detention and flood control volumes (Vpp/Vsd and $\mathrm{Vpp} / \mathrm{Vfc}$ ) were associated with improved pond efficiencies, both during normal functioning and cases where average negative removals occurred, viz.: (i) total copper and TSS correlated positively with Vpp/Vfc in the 'positive data only' section, (ii) total copper and zinc masses correlated positively with $\mathrm{Vpp} /$ Vsd in the 'positive data only' section, (iii) increased probability of significant positive total copper efficiencies were indicated by increases in $\mathrm{Vpp} / \mathrm{Vfc}$, (iv) decreased probability of average negative total zinc removals were indicated by increases in $\mathrm{Vpp} / \mathrm{Vfc}$.

This indicates that the volume within the permanent pool was of greater importance to pond efficiencies than the volume captured during storm events, which may simply have drained out of the ponds carrying material not removed within the retention times of the draining volumes. The mechanisms involved are unknown. It may be speculated that the association of many metals with suspended solids (Table 4) indicates that the volume acted as a buffer that reduced influent flow velocities, thereby improving sedimentation. Further research is warranted.

The same indications were found for pond surface areas, probably through relationships with pond volumes, viz.: (i) total copper mass correlated positively with SApp/SAsd in the 'all data' and 'positive data only' sections, (ii) increased probability of significantly positive total zinc removals were indicated by increases in SApp/SAsd, (iii) decreased probability of negative total lead and zinc fraction removals were indicated by increases in SApp/SAsd.

Increased permanent pool volume and surface areas in relation to the watershed area (Vpp/WA and SApp/WA) were also associated with increased pond efficiencies, viz. (i) total copper correlated positively with Vpp/WA in the 'all data' and 'positive data only' sections, (ii) increased probability of significantly positive particulate zinc efficiencies were indicated by increases in Vpp/WA and SApp/WA, (iii) decreased probability of average negative total cadmium removals was indicated by increased Vpp/WA and (iv) decreased probability of average negative dissolved and particulate zinc removals was indicated by increased SApp/WA.

Exceptions were (i) an increase in the probability of average negative TSS removals with increases in SApp/SAsd and (ii) decreased probability of significantly positive TVS efficiencies indicated by increases in Vpp/WA. The reasons for these contradictions are unclear.

Influent volumes may have facilitated mixing of material within the permanent pool with reduced efficiency as a result. Such a phenomenon was possibly indicated by (i) a negative TSS mass correlation with the SBF parameter, (ii) decreased probability of significantly positive total lead removal efficiencies with increases in SBF and (iii) increased probability of average negative TSS removals with increases in SBF. The results indicated deteriorating function with increased 
TABLE 4

Concentration/mass cross-correlation ( $p \leq 0.05, R \geq 0.8$ ) groups (values in brackets denote Spearman $R$ results, underlined values denote the main correlation parameter)

\begin{tabular}{|c|c|c|}
\hline Fractions & Concentrations & Masses \\
\hline \multicolumn{3}{|l|}{ Pond influent } \\
\hline Total & $\begin{array}{l}\text { 1. TSS and TVS }(0.85) \\
\text { 2. Copper and lead }(0.83) \text {, } \\
\text { TVS }(0.82)\end{array}$ & 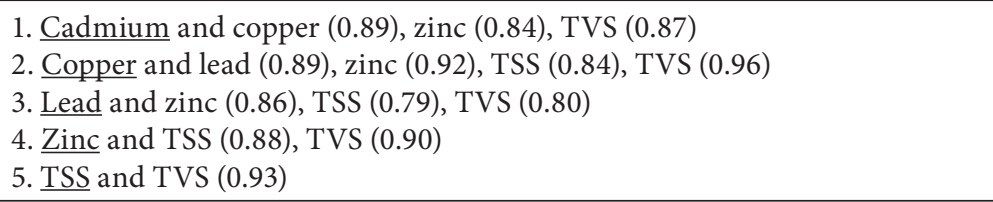 \\
\hline $\begin{array}{l}\text { Dissolved metals } \\
\text { and solids }\end{array}$ & $\begin{array}{l}\text { 1. Cadmium and TSS (0.81) } \\
\text { 2. } \underline{\text { TSS } \text { and TVS }(0.93)}\end{array}$ & $\begin{array}{l}\text { 1. Cadmium and lead }(0.90) \text {, zinc }(0.79) \text {, TSS }(0.86) \\
\text { 2. Copper and lead }(0.91) \text {, zinc }(0.83) \text {, TSS }(0.85) \\
\text { 3. Lead and zinc }(0.85) \\
\text { 4. Zinc and TSS }(0.83) \text {, TVS }(0.89)\end{array}$ \\
\hline Particulate & $\begin{array}{l}\text { 1. Copper and zinc }(0.86) \\
\text { 2. Lead and zinc }(0.82) \\
\text { 3. } \underline{\text { TSS } \text { and TVS }(0.79)}\end{array}$ & $\begin{array}{l}\text { 1. Cadmium and copper }(0.90) \text {, lead }(0.95) \text {, zinc }(0.96) \\
\text { 2. Copper and lead }(0.89) \text {, zinc }(0.92) \text {, TSS }(0.86) \\
\text { 3. Lead and zinc }(0.81) \\
\text { 4. Zinc and TSS }(0.86) \text {, TVS }(0.83) \\
\text { 5. TSS and TVS }(0.91)\end{array}$ \\
\hline \multicolumn{3}{|l|}{ Pond effluent } \\
\hline Total & None & $\begin{array}{l}\text { 1. Cadmium and copper }(0.88) \text {, lead }(0.87) \text {, zinc }(0.86) \text {, TSS }(0.86) \text {, TVS }(0.92) \\
\text { 2. Copper and lead }(0.96) \text {, zinc }(0.90) \text {, TSS }(0.89) \text {, TVS }(0.89) \\
\text { 3. Lead and zinc }(0.88) \text {, TSS }(0.89) \\
\text { 4. } \underline{\text { Zinc } \text { and TSS }(0.94)}\end{array}$ \\
\hline $\begin{array}{l}\text { Dissolved metals } \\
\text { and solids }\end{array}$ & None & None \\
\hline Particulate & $\begin{array}{l}\text { 1. Lead and zinc }(0.81) \\
\text { 2. } \underline{\text { Zinc }} \text { and TSS }(0.82)\end{array}$ & $\begin{array}{l}\text { 1. Copper and lead }(0.94) \text {, zinc }(0.87) \text {, TSS }(0.85) \\
\text { 2. Lead and zinc }(0.95) \text {, TSS }(0.93) \\
\text { 3. } \underline{\text { Zinc } \text { and TSS }(0.90)}\end{array}$ \\
\hline \multicolumn{3}{|l|}{ Fraction removed } \\
\hline Total & None & None \\
\hline $\begin{array}{l}\text { Dissolved metals } \\
\text { and solids }\end{array}$ & None & None \\
\hline Particulate & 1. Zinc and TVS (-0.90) & 1. Zinc and copper (0.84), lead (0.88) \\
\hline
\end{tabular}

surcharge brim-full emptying times, possibly due to increased mixing time.

Littoral zone surface area (SAlz) was negatively correlated with total copper mass removals in the 'positive data only' section. The ratio of littoral zone surface area to permanent pool surface area (SAlz/SApp) was positively correlated to TSS in the 'negative data only' section. This indicates that increases in littoral zone negatively affected pond efficiencies during normal pond functioning, possibly through reduction of effective capture volume and effects on pond hydraulics. However, during events where negative removals occurred, littoral zones decreased such removals, possibly by acting as a mechanical hindrance to wash-out of particulate material.

Apparently contrasting results for pond depth were found. Total copper removals correlated positively with the Vpp/SApp parameter in the 'all data' and 'positive data only' sections. Total lead ('all data' and 'positive data only' sections) and zinc ('all data' section) correlated negatively with the dpp parameter. In the logistic regression results, (i) decreased probability of significantly positive total lead efficiencies was indicated by increases in dpp, (ii) decreased probability of average negative total cadmium and particulate copper removals were indicated by increased Vpp/SApp and (iii) increased probability of average negative total lead and TSS removals were indicated by increased dpp.

Therefore, total copper mass removals were higher, and the probability of total cadmium and particulate copper negative removals lower, in ponds with increased depth. Conversely, for total zinc and lead removals, the probability of significantly positive total lead efficiencies and decreased probability of average negative total lead and TSS removals were higher in ponds with decreased depth. Total copper was associated with total zinc, lead and TSS removals in the cross-correlation section. These results indicate complexity in the effect of pond depth on metal removal not illuminated here.

\% Imperviousness of a catchment is used as a design parameter in published design methods (see Urban Drainage and Flood Control District, 2010 and Lampe, 2005). Few correlations with catchment $\%$ imperviousness were found. It was positively correlated with total zinc in the 'negative data only' section. This indicates that negative removals became less with increases in \% imperviousness of the watershed. In apparent contrast to this, \% imperviousness was a significant predictor for negative total copper removals. These results are not suggestive of any relationships and rather indicate that the 


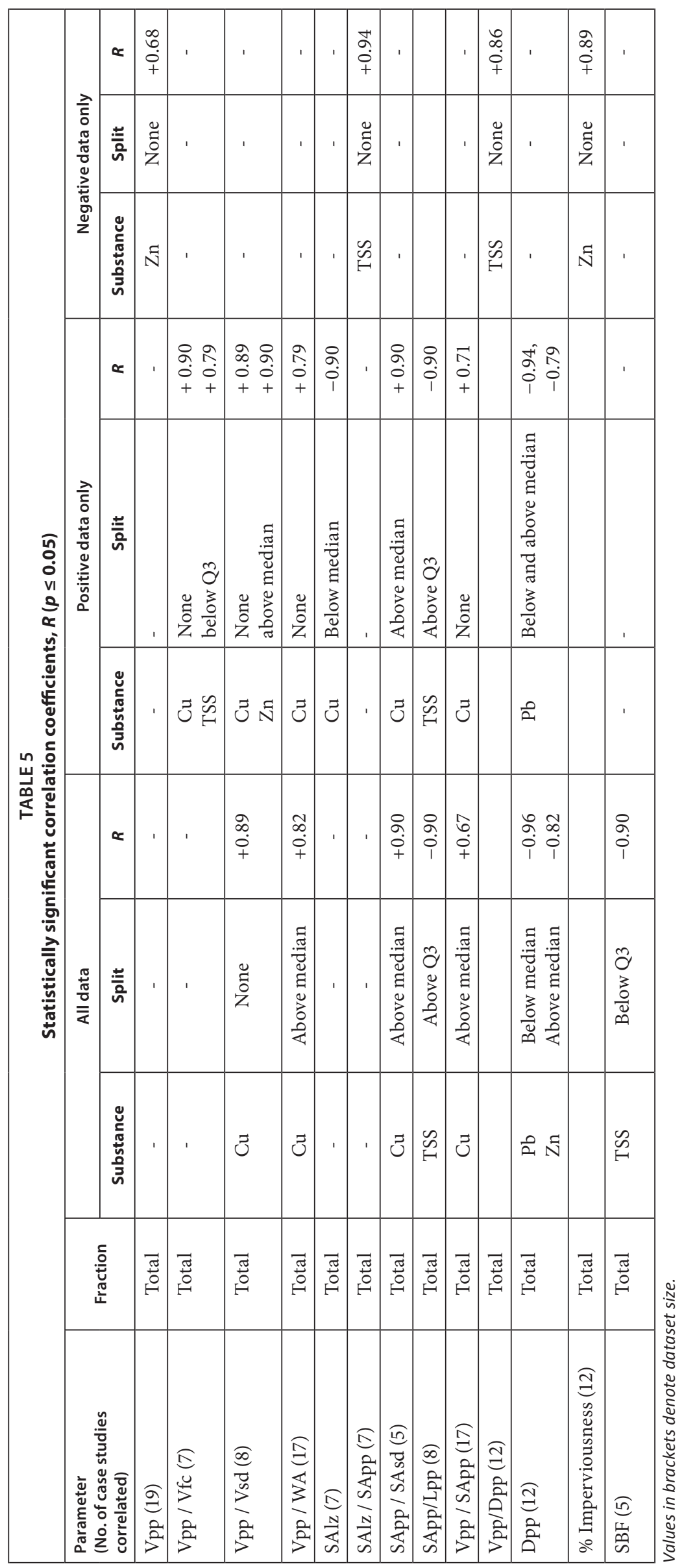




\begin{tabular}{|c|c|c|c|}
\hline \multicolumn{4}{|c|}{$\begin{array}{c}\text { TABLE } 6 \\
\begin{array}{c}\text { Significant }(p \leq 0.05) \text { physical pond parameter } \\
\text { efficiency predictors }\end{array}\end{array}$} \\
\hline Substance & Total fraction & Dissolved fraction & $\begin{array}{l}\text { Particulate } \\
\text { fraction }\end{array}$ \\
\hline Copper & $\mathrm{Vpp} / \mathrm{Vfc}$ & - & - \\
\hline Lead & $-\mathrm{dpp},-\mathrm{SBF}$ & - & - \\
\hline Zinc & $\begin{array}{c}\text { SApp/SAsd, } \\
\text {-dpp }\end{array}$ & - & $\begin{array}{l}\text { Vpp/WA, } \\
\text { SApp/WA }\end{array}$ \\
\hline TVS & $-\mathrm{Vpp} / \mathrm{WA}$ & - & - \\
\hline
\end{tabular}

Relationships between pond efficiencies and pond physical characteristics

1. In no cases did concentration removal correlations have corresponding mass removal correlations, showing that concentration and mass variables were not interchangeable.

2. The results indicated that removals were differently influenced by pond parameters over different data ranges. This indicates that design of retention ponds should include consideration of the runoff load magnitudes.

3. The volume within the permanent pool was of greater importance to pond efficiencies than the volume captured during storm events. However, correlations with this parameter were not found directly, indicating that the ponds operated as complex systems. Therefore, the permanent pool volume was important to the functioning of the ponds, but was only one part of complex systems. For example, it was also indicated that increases in the littoral zone negatively affected pond efficiencies during normal pond functioning, possibly through reduction of effective capture volume and effects on pond hydraulics. However, during events where negative removal occurred, littoral zones decreased such removals, possibly by acting as a mechanical hindrance.

4. Negative correlations with surcharge brim-full emptying times indicated that influent volumes may have facilitated mixing of material within the permanent pool with reduced efficiency as a result, possibly due to increased mixing times.

5. Apparently contrasting results for pond depth and $\%$ imperviousness of the site were found. This indicates complexity in the relationship between these parameters and metals removal not illuminated here.

placement of importance on \% imperviousness in design is unwarranted.

\section{CONCLUSIONS}

\section{Pond efficiencies over different data ranges}

Statistically significant differences between upper and lower data ranges for influent data indicated that pond efficiencies, defined as fraction removals, differed between high and low influent concentrations and masses. This provides support to the notion of different removals at different concentrations, i.e., that discharge concentrations may be a function of influent concentrations, and adds the knowledge that this also applies to masses.

\section{Cross-correlations between metals and solid substances}

1. Mass, as opposed to concentration, was accepted as a more valid indicator of correlations between substances in pond influent and effluent streams as well as the fractions of substances removed within ponds.

2. Mass results indicated that total cadmium, copper, lead, zinc and TSS were associated in surface runoff and were similarly removed within ponds. Retention pond design should therefore focus on the process of sedimentation. All dissolved substances correlated with TSS in the influent section. Dissolved zinc also correlated with TVS. This may have been due to an external relationship between these substances and flow volumes. Correlations in effluent and fraction-removed sections indicated that TSS was associated with particulate copper, lead and zinc removals within ponds.

\section{Design recommendations}

- Metal mass correlations with suspended solids in influent, effluent and removals indicate that retention pond design should focus on sedimentation.

- Additionally to the first point above, the occurrence of negative removals, i.e., occasions where outflow masses were greater than inflow masses during storm events, indicated resuspension of previously removed materials. Future pond design should therefore include elements to prevent resuspension. Failure to do so will negate the benefits of initial material removal, since these can simply be washed out of the pond during later storm events.

- Statistically significant differences between upper and lower mass removal groups indicates that pond design should consider the expected runoff load from a catchment to ensure correct design response.

\section{Future research}

The results of this investigation elucidated relationships between retention pond parameters and pollutant (metals and solids) removals. These may be used to inform design efforts towards stormwater quality improvement. The results, however, do not provide a full understanding of pollutant removal mechanisms (s.a. sedimentation) within ponds. Future research towards improving design methods for water quality improvement in retention ponds should therefore focus on understanding such mechanisms. 


\section{REFERENCES}

BARRETT ME (2008) Comparison of BMP performance using the International BMP database. J. Irrig. Drain. Eng. 134 (5) 556-561. https://doi.org/10.1061/(ASCE)0733-9437(2008)134:5(556)

BORRIS M, OSTERLUND H, MARSALEK J and VIKLANDER $M$ (2016) Contribution of coarse particles from road surfaces to dissolved and particle-bound heavy metal loads in runoff - A laboratory leaching study with synthetic stormwater. Sci. Total Environ. 573 212-221. https://doi.org/10.1016/j.scitotenv.2016.08.062

BRINK IC (2016) Design of stormwater ponds towards the reduction of metal toxins in surface waters that are utilised for South African primary food production. PhD thesis, University of Stellenbosch.

BRINK IC and KAMISH W (2016a) Stormwater pond metals and solids removal efficiency determination with the effluent probability method: a novel classification system. J. S. Afr. Inst. Civ. Eng. 58 (2) 49-55. https://doi.org/10.17159/2309-8775/2016/ v58n $2 \mathrm{a} 6$

BRINK IC and KAMISH W (2016b) Stormwater pond efficiency determinations with the effluent probability method: the use of mass versus concentration parameters. J. S. Afr. Inst. Civ. Eng. $\mathbf{5 8}$ (2) 42-48. https://doi.org/10.17159/2309-8775/2016/v58n2a5

CALIFORNIA DEPARTMENT OF TRANSPORTATION (2004) BMP retrofit programme - Final report. Caltrans, Sacramento. URL: www.dot.ca.gov (Accessed 10 November 2011).

COMINGS KJ, BOOTH DB and HORNER RR (2000) Stormwater pollutant removal by two wet ponds in Bellevue, Washington. J. Environ. Eng. 126 (4) 321-330. https://doi.org/10.1061/ (ASCE)0733-9372(2000)126:4(321)

DWAF (Department of Water Affairs and Forestry, South Africa) (1996) South African Water Quality Guidelines Volume 4 Agricultural Use: Irrigation ( $2^{\text {nd }}$ edn). Department of Water Affairs and Forestry, Pretoria. URL: www.dwaf.co.za (Accessed 25 February 2011).

DJUKIĆ A, LEKIĆ B, RJAKOVIĆ-OKNJANOVIĆ V, VELJOVIĆ D, VULIĆ T, DJOLIĆ M, NAUNOVIC Z, DESPOTOVIĆ J and PRODANOVIĆ D (2016) Further insight into the mechanism of heavy metals partitioning in stormwater runoff. J. Environ. Manage. 168 104-110. https://doi.org/10.1016/j. jenvman.2015.11.035

DUFRESNE M, DEWALS BJ, ERPICUM S, ARCHAMBEAU P and PIROTTON M (2010) Experimental investigation of flow pattern and sediment deposition in rectangular shallow reservoirs. Int. J. Sediment Res. 25 (3) 258-270. https://doi.org/10.1016/ S1001-6279(10)60043-1

GREB SR and BANNERMAN RT (1997) Influence of particle size on wet pond effectiveness. Water Environ. Res. 69 (6) 1134-1138. https://doi.org/10.2175/106143097X125876

HARPER HH and HERR JL (1993) Treatment efficiencies of detention with filtration systems. Environmental Research and Design, Inc., Orlando. URL: www.sjrwmd.com (Accessed 1 November 2011).

HOSSAIN MA, ALAM M, YONGE DR and DUTTA P (2005) Efficiency and flow regime of a highway stormwater detention pond in Washington, USA. Water, Air Soil Pollut. 164 79-89. https://doi. org/10.1007/s11270-005-2250-1

HOUSE LB, WASCHBUSCH RJ and HUGHES PE (1993) Water quality of an urban wet detention pond in Madison, Wisconsin, 1987-1988. U.S. Geological Survey, Denver.URL: pubs.usgs.gov (Accessed 15 November 2011).

INTERNATIONAL STORMWATER BMP DATABASE (Version 07.07.11) (2012) URL: www.bmpdatabase.org (Accessed 8 February 2012).

KANG JH, LEE YS, KI SJ, LEE YG, CHA SM, CHO KH and KIM JH (2009) Characteristics of wet and dry weather heavy metal dishcarges in the Yeongsan Watershed, Korea. Sci. Total Environ. 407 3482-3493. https://doi.org/10.1016/j.scitotenv.2009.02.021

KANG JH, LEE SW, CHO KH, KI SJ, CHA SM and KIM JH (2010) Linking land-use type and stream water quality using spatial data of fecal indicator bacteria and heavy metals in the Yeongsan river basin. Water Res. 44 4143-4157. https://doi.org/10.1016/j. watres.2010.05.009

KANTROWITZ IH and WOODHAM WM (1995) Efficiency of a stormwater detention pond in reducing loads of chemical and physical consituents in urban streamflow, Pinellas County, Florida.
United States Geological Survey, Denver. URL: fl.water.usgs.gov (Accessed 11 June 2012).

LAMPE L (2005) Performance and whole life costs of best management practices and sustainable urban drainage systems. IWA Publishing, London.

MARTIN EH and SMOOT JL (1986) Constituent-load changes in urban stormwater runoff routed through a detention pond-wetlands system in central florida. United States Department of the Interior, Tallahassee. URL: pubs.usgs.gov (Accessed 15 November 2011).

NAITO W, KAMO M, TSUSHIMA K and IWASAKI W (2010) Exposure and risk assessment of zinc in Japanese surface waters. Sci. Total Environ. 408 4271-4284. https://doi.org/10.1016/j. scitotenv.2010.06.018

OBERTS GL, WOTZKA PJ and HARTSOE JA (1989) The water quality performance of select urban runoff treatment systems. Metropolitan Council of the Twin Cities Area, St. Paul. URL: www. epa.gov (Accessed 17 November 2011).

PLAUBORG F, ANDERSEN MN, LIU F, ENSINK J and RAGAB R (2010) Safe and high quality food production using low quality waters and improved irrigation systems and management: SAFIR. Agric. Water Manage. 98 377-384. https://doi.org/10.1016/j. agwat.2010.05.020

RUSHTON B, MILLER C, HULL C and CUNNINGHAM C (1997) Three design alternatives for stormwater detention ponds. South West Florida Water Management District, Brooksville. URL: www. swfwmd.state.us (Accessed 8 November 2011).

RUSHTON BT (2002) Treatment of stormwater runoff from an agricultural basin by a wet-detention pond in Ruskin, Florida. URL: www.swfwmd.state.fl.us (Accessed 9 November 2011).

STORMWATER ASSESSMENT MONITORING AND PERFORMANCE (SWAMP) PROGRAMME (2005) Synthesis of monitoring studies conducted under the stormwater assessment monitoring and performance programme. Toronto and Region Conservation Authority, Toronto. URL: www. sustainabletechnologies.ca (Accessed 8 November 2011).

STRECKER EW, QUIGLEY MM, URBONAS BR, JONES JE and CLAREY JK (2001) Determining urban stormwater BMP effectiveness. J. Water Resour. Plann. Manage. 127 (3) 144-149. https://doi.org/10.1061/(ASCE)0733-9496(2001)127:3(144)

STRIEGL RG and COWAN EA (1987) Relations between quality of urban runoff and quality of Lake Ellyn at Glen Ellyn, Illinois. United States Government Printing Office, Denver. URL: pubs. usgs.gov (Accessed 9 November 2011).

UNEP (United Nations EnvironmentProgramme) (2006) Water quality for ecosystem and human health. URL: www.gemswater.org (Accessed 16 May 2011).

UNEP (United Nations Environment Programme) (2010) Clearing the waters - a focus on water quality solutions. UNON, Nairobi. URL: www.unep.org (Accessed 8 February 2012).

USEPA (United States Environmental Protection Agency) (1983) Results of the nationwide urban runoff programme, Volume 1. URL: cfpub.epa.gov (Accessed 15 February 2015).

URBAN DRAINAGE AND FLOOD CONTROL DISTRICT (2010) Urban storm drainage criteria manual - volume 3. Urban Drainage and Flood Control District, Denver. URL: www.udfcd.org (Accessed 8 November 2011).

WALKER JF (1993) Techniques for detecting effects of urban and rural land-use practices on stream-water chemistry in selected watersheds in Texas, Minnesota and Illinois. U.S Geological Survey, Madison. URL: pubs.usgs.gov (Accessed 15 November 2011).

WETLAND SOLUTIONS INC. (2010) Greens Bayou wetlands mitigation bank subdivision B - water quality facility. URL: wetlandsolutionsinc.com (Accessed 9 November 2011).

WRIGHT WATER ENGINEERS INC., GEOSYNTEC CONSULTANTS INC. (2010) International Stormwater Best Managment Practices (BMP) Database - user's guide for BMP data entry spreadsheets. URL: www.bmpdatabase.org (Accessed 17 May 2011).

WU JS (1989) Evaluation of detention basin performance in the Piedmont region of North Carolina. Water Resources Research Institute, Charlotte. URL: repository.lib.ncsu.edu (Accessed 14 June 2012).

ZGHEIB S, MOILLERON R, CHEBBO G (2012) Priority pollutants in urban stormwater: Part 1 - case of separate storm sewers. Water Res. 46 (20) 1-10. https://doi.org/10.1016/j.watres.2011.12.012 